\title{
Det umuliges kunst
}

- Om Alenka Zupančič' teori om komedien

\section{Indledning}

Ærindet med den følgende artikel er at fremstille den teori om komedie, som er blevet fremlagt af Alenka Zupančič i bogen The Odd One In fra 2008. Artiklen beskriver, hvori komediens væsentligste træk ifølge Zupančič består, og fokuserer desuden på at redegøre for de inspirationskilder, der ligger til grund for teorien. Artiklen lægger ud med at redegøre for den inspirationskilde, der udgøres af G. W. F. Hegel, og bevæger sig dernæst videre til den vægtigere inspirationskilde, der udgøres af Jacques Lacan. Artiklen påpeger dog også, hvordan det netop er i kombinationen af de to, at Zupančič’ teori frem for alt udformes, ligesom det er i kraft af denne kombination, at hendes teori mest interessant adskiller sig fra andre teorier om komedie.

The Odd One In bærer, som Alenka Zupančič skriver, den "(ikke helt) ydmyge ambition" at ville give komedien sin kant og begrebslige skarphed tilbage (Zupančič 2008: 9). ${ }^{1}$ Dette udsagn skal forstås i opposition til en typisk og udbredt opfattelse, der henregner komedien til det umiddelbare, det folkelige og det ureflekterede. Det er i det hele taget, som om der til stadighed knytter sig en pudsig dobbelthed til komikken, for mens den videnskabelige og filosofiske tradition fra begyndelsen har regnet komedien blandt de klassiske kunstformer, bliver selve det at beskue og'forstå' komik alligevel typisk defineret ud fra en simpel menneskelig reaktion: Latter. I virkeligheden er både latter og komedie særdeles komplicerede fænomener, og det er netop komediens betydelige kvalitet, at den formår at give nogle af de mest fundamentale konflikter i mennesket og dets virkelighed et konkret udtryk. ${ }^{2}$ For at få blik for disse kvaliteter, kræver det imidlertid, at man tør gå til komedien med et systematisk begrebsapparat og en ambition om at skabe en nuanceret og differentieret beskrivelse af de forskelligartede mekanikker, som komediekunsten indeholder. Det er denne ambition om at genfinde det komplicerede i det tilsyneladende simple, som præger Zupančič bog, og dette er i sig selv et af de træk, der placerer hende indenfor det, der i nærværende tidsskrift kaldes 'den slovenske skole.' 


\section{Baronen og bananskrællen}

Betoningen af komedien og latteren som noget universelt menneskeligt er udbredt i vor tradition og danner som sådan også et udgangspunkt for Zupančič' teori. Komik tjener til at skabe den lethed i en social orden, som er nødvendig for, at mennesker overhovedet kan eksistere i den. Komikken er for subjektet en ventil, en slags tilværelsens undtagelsesvise ombudsmand, der skaber plads og giver luft, når systemet og strukturerne strammer for hårdt. Vi taler om latteren som 'forløsende' og 'befriende', når situationer bliver for opstyltede og pinagtige. I filosofien finder vi elementer af denne tankegang hos Aristoteles, når han beskriver den katarsiske virkning af komedien (og i øvrigt sidestiller komedien, der beskriver menneskets grimme eller slette træk, med tragedien, der handler om menneskets ædle træk) (Aristoteles 2009). Vi finder det også i Freuds teori om vitsen (Freud 1994), hvori det komiske beskrives gennem dets effekt hos subjektet: at tillade udladningen af slette, grimme, eller simpelthen konfliktfyldte impulser i psyken.

Et eksempel på komediens forløsende effekt kan beskrives med den følgende velkendte sekvens: En baron kommer gående hen ad gaden, glemmer at se sigfor, og glider i en bananskrel. Vi har her at gøre med god gammeldags lagkagekomik. Når baronen falder, forløses den pinagtige tilstand af selvhøjtidelig patos, der hidtil har præget situationen, vi griner ad det, og oplever samtidig, at baronen reduceres til det, han i virkeligheden er, et simpelt menneske som os selv. Når komedien former sig på denne måde, kan den fungere som en påpegning af, at nogen har båret sig ad på en etisk kritisabel måde, hvilket indfanger det syn på latter, som findes hos f.eks. Thomas Hobbes ${ }^{3}$ (1996: 35) og Henri Bergson (1993: 27). Samtidig er mange klassiske tænkere imidlertid enige om i komedien også at se et element af 'lethed' og en overbærende holdning til den menneskelige dårskab. Latter og komedie hjælper os til accept af, at 'ikke alle er perfekte', at tingene ikke altid kan gå som man ønsker sig osv.

Denne karakteristik beskriver imidlertid kun én side af komedien, en side som ifølge Zupančič kun "når halvvejs ud ad det komiske spor", og som i en politisk forstand ligefrem kan betragtes som reaktionær. (Zupančič 2008: 31). Heroverfor stiller hun, hvad hun kalder den egentlige eller sande komedie, der snarere end kortvarigt at lukke luften ud af en given social situation, opretholder en konflikt og udvikler den. Mens den kortvarige komik kun tilbyder et hurtigt afbræk fra arbejdet i den symbolske og ideologiske orden, et glædeligt frikvarter der fremmaner en momentan oplevelse af magtens fravær, hvorefter det er tilbage til arbejdet, så afstedkommer den egentlige 
komik en ægte kollision i den symbolske orden, en slags kortslutning, der i visse tilfælde endda kan føre frem til en varig ændring af den symbolske ordens koordinater og strukturer.

Hvis vi vender tilbage til eksemplet med baronen og bananskrællen, ligger det egentligt komiske ifølge Zupančič ikke blot i, at baronen skvatter, men i det typiske efterspil, hvor baronen hurtigt og bestemt rejser sig op, børster frakken af, og som om intet var hændt fortsætter sin vandring - indtil han kort efter overser noget nyt og således igen må en tur i sølet (Zupančič 2008: 29ff.). Mens det første aspekt af komikken baserer sig på en skelnen mellem det naturligt menneskelige (glid i bananskrællen) og det kunstigt opretholdte (aristokrati), så peger det andet aspekt på, at denne dualitet mellem det lave og det høje sagtens kan omvendes eller ligefrem blandes uigenkaldeligt sammen. For hvad er egentlig det mest latterlige ved mennesket $\mathrm{i}$ denne situation? Er det kroppens fejltrin, eller er det den overdrevne tro på ens egen adelighed? Hvis det mest komiske i denne sammenhæng ikke blot er kroppens evne til at falde, men snarere menneskets evne til at opretholde facaden og blive ved med at tro på sin egen ærværdighed trods alle tildragelser, så angår komedien pludselig mere end bare personen selv: den angår rent faktisk aristokrati og adelighed som sådan.

\section{Hegel og det åndelige kunstværk}

Zupančič opbygger denne pointe gennem en læsning af Hegel, der i kapitel 7 af Andens Fenomenologi (Hegel 2005) opstiller en dialektisk udviklingsserie for det såkaldte åndelige kunstværk'. Først i denne serie kommer det græske epos, dernæst tragedien, og til sidst komedien som det højst udviklede kunstværk af de tre, og som det der logisk set fungerer som det sidste skridt frem mod den kristne 'kunstreligion'. Denne måske overraskende udviklingskæde skyldes Hegels specielle perspektiv på kunsten som udtryk for åndens dialektiske kommen-til-sig-selv igennem medieringer mellem det almene og det individuelle, mellem højere almene og historiske fornuftsstrukturer, og så de konkrete personer og instanser, der skal repræsentere dem.

I eposset får vi beskrevet de græske helte, hvordan de lever, kæmper, begår sig og undervejs ses at fremstille en større historisk skæbne. Historiens gang dikteres i vid udstrækning fra den højere verden, hvor guderne regerer, og gennem sangeren (eller skjalden) fortælles historien om, hvordan specifikke mennesker, og ikke mindst helte, realiserer hele dette spil (Hegel 2005: 507). Undervejs tager denne handling form af forskellige konflikter, hvor gudernes 
verden bringes i kontakt med den menneskelige, hvor guder opfører sig som individer, og mennesker inkarnerer større bestemmelser. Således er der allerede her en mediering på spil mellem det almene, der skulle repræsenteres, og det konkrete, der skulle repræsentere, om end denne mediering endnu ikke er så udviklet som i de senere kunstformer (Hegel 2005: 508).

I tragedien nærmer medieringen sig en tættere forbindelse mellem de to poler. Her har forestillingen fralagt sig skjalden som mellemmand og fremvises nu direkte af individuelle skuespillere på scenen, således at det nu, som Hegel siger, er heltene selv, der taler (Hegel 2005: 510). Dertil kommer, at disse skuespillere som karakterer handler i en mere ren og idealistisk form "helt befriet for tilfældige omstændigheder og private ejendommeligheder." (Hegel 2005: 511). Samtidig bliver det klart, at de konflikter der opstår i tragedien, ikke blot skyldes forholdet mellem det almene og det individuelle, mellem religiøse og politiske idealer og så de konkrete mennesker, der lever under dem, men at konflikterne i høj grad skyldes et misforhold mellem de ideelle ordener selv. Når tragedien konfronterer uforligelige systemer og værdier og lader sine hovedpersoner gå til grunde i disse konflikter, så gentager koret dog i sidste ende blot en nytteløs klage over denne kranke skæbne, og således forbliver en vis afstand mellem det individuelle og det almene stadig intakt i tragediens kunstform (Hegel 2005: 512).

Som tredje instans finder vi imidlertid komedien, hvor forholdet mellem det almene og det individuelle opnår en endnu tættere sammenknytning. Det interessante ved komedien er ikke blot, at den fremviser et menneske, der mere eller mindre bevidst gør noget uheldigt og i sidste ende må betale prisen for det (sådan som det typisk er tilfældet i tragedier). Det interessante er, hvordan det individuelle her fungerer som en inkarnation af det almene på en måde, så det almene selv kommer til at ændre karakter. I komedien ophæves repræsentationsforholdet, så det ikke længere er det individuelle, der repræsenterer det almene, i stedet kollapser forholdet simpelthen. Det skyldes ikke blot den komiske figurs manglende evne til at inkarnere de højere idealer, det skyldes ligeså meget en grundlæggende konflikt i subjektet selv. Som subjekt er det negative i ham, og i hans forsøg på at inkarnere idealer, brydes disse idealer ligeledes. Det individuelle, den komiske person, er, som Hegel siger, "selv den negative kraft, takket være og i hvilken såvel guderne som deres momenter, dvs. den derværende natur og tankeindholdet $\mathrm{i}$ deres bestemmelser, forsvinder." (Hegel 2005: $519 \mathrm{ff}$.). I de komiske sekvenser sker der således en mediering - eller snarere ligefrem en kortslutning - mellem det almene og det konkrete. Her sættes det almene, som Zupančič for- 
mulerer det, "i arbejde", ${ }^{4}$ så det ikke længere er til at se, hvad der er alment, og hvad der er konkret. Det kan illustreres ved at vende tilbage til baronen og bananskrællen.

Mens en umiddelbar komisk tilgang ville se baronens træge korpus som hans mest konkrete manifestation og hans klæder og insignier som de kunstige symboler på hans (kunstige) adelstand, hans position i det almenes institutionelle orden, så er det sandt komiske ifølge Zupančič, at denne adelighed nu viser sig $i$ kroppen, i dens fald og bevægelser fra mudderpøl til mudderpøl, fra bananskræl til bananskræl. Det er ikke blot i selve faldet, at baronen er komisk, det er mest af alt i sin nærmest mekaniske måde at rejse sig op, børste sig af, gå videre osv., at baronens tro på sin adelsmæssige overlegenhed gemmer sig. Pludselig bliver det således også i netop disse gestus, at adeligheden som sådan inkarneres. Det følgende citat opsamler denne pointe:

\begin{abstract}
En sand komedie om en hovmodig baron må fremstille den følgende formel i al sin materialitet: En aristokrat der tror, at han virkelig og af indre nødvendighed er en aristokrat er, $i$ selve denne tro, et sølle, almindeligt menneske. Med andre ord må en sand komedie om aristokrati spille sine kort på en sådan måde, at dette begrebs almene aspekt producerer sin egen menneskelighed, legemlighed og subjektivitet. Her er kroppen ikke bare en uundværlig basis for sjælen. En klippefast tro på egen baron-status er netop det punkt, hvor sjælen bliver så legemlig og håndgribelig som muligt. Baronens konkrete legeme, som gang på gang falder i pølen med menneskelige svagheder, er ikke bare en empirisk krop, der ligger udstrakt i mudderet, men udgør mere end noget troen på hans egen baron-stand, hans "baronitet". Denne "baronitet" er det ægte komiske objekt, produceret af komedien som en kvintessens af selve det almene (Zupančič 2008: 31f.).
\end{abstract}

\title{
Det umuliges kunst og inspirationen fra Lacan
}

Hvis den ene vigtige inspirationskilde til Zupančič' teori om komedien er Hegel, så findes der en måske endnu større inspirationskilde i Lacan. Men hvor Hegels bidrag består i et bestemt, fast og allerede defineret perspektiv på komedien, så består den inspiration, der kommer fra Lacans forfatterskab, snarere i en række spredte, kortfattede formuleringer og tekstpassager, der ikke i sig selv forklarer eller definerer komedien eller dens virkemidler, men indikerer aspekter af den, som en grundigt arbejdende filosof vil kunne forfølge i yderligere studier. I Zupančič fortolkning af Lacan bliver især begrebet om det lille objekt a (objet petit a) vigtigt, idet det fungerer som et be- 
grebsligt prisme, hvorigennem vi kan se en lang række komiske mekanismer udfolde sig. I det følgende afsnit skal vi se nærmere på begrebet om objekt $a$, der i kraft af at være 'et umuligt objekt' bliver centralt for enhver komedie.

For hvori består det egentligt komiske? Ifølge Zupančič opstår komikken frem for alt, når to uforenelige størrelser eller realiteter mødes. Man plejer gerne at kalde politikken for 'det muliges kunst' - fra Zupančič perspektiv kunne man med god ret definere komedien som 'det umuliges kunst'. Komedien iscenesætter et møde mellem to ting, der ikke kan, ikke burde, eller ikke burde kunne mødes. Som når den kazakhstanske tv-vært Borat ${ }^{5}$ bærer en pose frees med ind til et fint middagsselskab (hvilket han ikke burde), som når Mickey Mouses hund Pluto ${ }^{6}$ løber i ring og forsøger at fange sin egen hale (hvad den ikke kan), eller som når katten i Tom og Jerry bliver ved med at løbe lige ud i luften uden at falde i afgrunden (hvad den ikke burde kunne), fordi den endnu ikke har opdaget, at den for længst er trådt ud over kanten. Udtrykket 'burde kunne' er måske næsten det mest passende her, for det påpeger netop det register af 'det umuliges realisering', der kendetegner komedien. Om noget må det siges om komedien, at her sker det umulige, jævnligt endda. Eller mere præcist: Det umulige bliver ved med at udfolde sig.

Den teoretiske definition af 'det umulige', som Alenka Zupančič abonnerer på, er hentet fra Jacques Lacan, hvor det umulige typisk associeres med registret det reelle, og hvor det reelles mest håndfaste manifestation tager form af det såkaldte lille objekt $a$. For at beskrive objekt $a$ 's præcise definition er det nødvendigt med en kort redegørelse.

Lacan skelner mellem tre registre af subjektets virkelighed, det imaginare, det symbolske og det reelle. Begreberne er i første om gang kliniske: De har til formål at indfange og inddele de fænomener, der kan observeres i en psykoanalyse. De anvendes dog typisk med en større teoretisk rækkevidde, og Lacan bruger dem ofte simpelthen til at beskrive subjektet og dets væren i det hele taget, hvorved begreberne kommer tæt på at få en ontologisk karakter. ${ }^{7}$

Det imaginare register beskriver de sider af subjektets erkendelse og væren, der har at gøre med identitet og et relativt fast forankret jeg (eller 'ego'). Jeg'et dannes og opretholdes i form af identifikationer med individets medmennesker. Idet jeg identificerer mig med de andre, gør jeg så at sige to ting: Jeg identificerer dem som faste og enhedslige størrelser, der kan skelnes fra alt det andet udflydende stof, verden er gjort af. Samtidig identificerer jeg mig med dem ved at forholde mig (selv) til dem, spejle mig i dem og interagere med dem. Således indeholder identifikationen også et element af objektgørelse. Idet jeg danner mig en identitet, gør jeg mig til en afgrænset 
størrelse i verden, en størrelse blandt andre afgrænsede størrelser.

Det symbolske register betegner niveauet for sproget og de sociale strukturer, der determinerer subjektet og bestemmer dets væren. Sproget forstås i forlængelse af Ferdinand de Saussure som et strukturelt system, hvor tegnenes betydninger kun opretholder sig i kraft af referencen til andre tegn. Mens Saussure skelner mellem tegnets materielle og mentale korrelat, betegneren og det betegnede, ${ }^{8}$ lægger Lacan imidlertid hovedvægten på betegneren som sådan. Sproget består ifølge Lacan essentielt kun af betegnere, og det betegnede skal således blot forstås som en undertrykt betegner, en betegner som er fraværende i vor konkrete diskurs, men som de udtalte betegnere henviser til. Groft sagt henviser et ord derfor ikke til tanker, men til andre ord og ordformationer, der eksisterer i diskurser og i subjekters hukommelse. Således er de fraværende betegnere, og de fraværende tegnstrukturer, netop Lacans definition på det ubevidste: Det er alle de betegnere, som vi ikke har præsent, når vi taler om os selv og verden, men som ikke desto mindre 'klinger med' i betydningsdannelsen. Det er typisk hele dette symbolske system, bevidst såvel som ubevidst, der af Lacan betegnes den Anden.

Subjektet er kendetegnet ved, at det på den ene side lever i og gennem sproget, og at det på den anden side oplever en konstant fremmedgørelse og separation fra verden i kraft af sprogets mekanismer. Subjektet er som sådan selv det mest radikale udtryk for, at verden i kraft af sproget er delt i to, det præsente og det ikke præsente, hvilket blandt andet viser sig ved, at der altid er noget ubevidst og symptomatisk i subjektets gøren og laden. Subjektet er på den ene side det talende, symbolske subjekt og på den anden side det ubevidste, i sidste ende reelle, subjekt.

Det reelle betegner i Lacans teori nemlig den rest, der bliver til overs, når subjektet dannes i kraft af det imaginære og det symbolske. Det reelle er det ikke-symboliserbare, som dog ikke desto mindre manifesterer sig, for eksempel i form af symptomer, der bliver ved med at plage os, selvom vi ikke kan sætte ord på hvad de betyder, eller i form af den modsatte effekt, at et ord pludselig kan blive meningsløst for os og stå tilbage som en underlig, fjollet lyd. Det essentielle ved det reelle er således, at det melder sig for os og dermed indebærer en konflikt i den verden, vi normalt forstår og ved hjælp af symboler orienterer os i. Det reelle er noget ikke-sprogligt, der dukker op i det sproglige (og for eksempel giver effekter af absurditet, meningsløshed, komik eller uhygge). Ligeledes er det reelle i konflikt med det imaginære, fordi det frembyder oplevelsen af noget, vi ikke kan identificere eller identificere os med. 
Når der er en konflikt i den symbolske orden eller i subjektets forhold til den, så er det reelle altså til stede, og denne konflikt centrerer sig mere specifikt om det reelle objekt, det såkaldte lille objekt $a$, der således ikke er et objekt i nogen almindelig forstand, men snarere er et objekt, der er umuligt at få styr på. Når den anden optræder på en måde, der gør det umuligt for mig at identificere mig med vedkommende, så er det eksempelvis, fordi jeg i hende ser dette lille ekstra, det irriterende objekt a. Samtidig er det dette lille ekstra, som for subjektet kan gøre den anden attråværdig - til en man begærer eller elsker. Det er en essentiel del af den lacanianske teori at betone sådanne paradoksale eller konfliktfyldte sider af den menneskelige virkelighed: Jeg elsker dig, men jeg hader dig, jeg begærer dig, men jeg ved ikke hvad det er i dig, jeg begærer, jeg finder nydelse ved mit liv, men samtidig er jeg aldrig rigtig tilfreds.

\section{Komediens vinkel}

Væsentligt ved det lille objekt $a$ er, at det for subjektet både er anledning til oplevelser af mangel (manglende tilfredsstillelse, manglende forståelse, manglende tolerance, manglende selvidentitet og selvkontrol) og oplevelser af for-meget-hed (samt overraskelse og overskud). Objekt $a$ optræder både som en mangel i verden $o g$ det modsatte, og kan derfor siges på samme tid at installere et -1 og et +1 i verden. Objekt $a$ kan altså både være udtryk for at noget mangler i verden, og at der er noget ekstra eller for meget til stede i verden. At ting i verden opleves som meningsløse indebærer også, at ting kan begynde at give meget mere mening, end der umiddelbart var tilgængelig. Perspektiverne er vigtige her, for det er netop på dette punkt, at komedien ifølge Zupančič adskiller sig fra tragedien. Tragedien er manglens genre, mens komedien er overskuddets, overraskelsens og "succesens" genre (Zupančič 2008: 130f.). Klodshans er eksempelvis ikke bare komisk, fordi han opfører sig som en idiot og kommer galt af sted, men fordi han faktisk vinder prinsessen og det halve kongerige. Eller rettere: Klodshans er komisk, fordi han faktisk opfører sig som en idiot $o g$ vinder prinsessen og det halve kongerige. I selve den proces, der udfoldes med Klodshans som omdrejningspunkt, ændres selve betingelserne for, hvad det vil sige at søge adgang til hoffet med dets regler for indgåelse af æateskab. ${ }^{9}$

Med dette in mente kan vi nu opsamle Alenka Zupančič overordnede definition af komediens tilgang til 'det umulige', ligesom vi vil kunne se hendes forskellige eksempler på komedie som tematikker, der udspringer fra et 
overordnet perspektiv. Når jeg brugte Klodshans som eksempel betyder det nemlig ikke, at alle komedier nødvendigvis ender lykkeligt. Pointen er, at komedien iscenesætter en konflikt og dernast udvikler den. Konflikten kan her meget vel fortsætte med at være konflikt, den artikuleres blot på nye måder. Et af de særligt gode eksempler på denne definition giver Zupančič i form af noget så simpelt som en reklame for mobiltelefoni. Passagen fortjener at blive citeret i sin fulde længde:

Den overordnede kontekst er et (stereo)typisk tilfælde af utroskab: En mand kommer hjem fra arbejde lidt tidligere end normalt og finder sin kone i sengen. Hun er tydeligt overrasket over hans hjemkomst og hævder at ligge i sengen på grund af en frygtelig hovedpine. Mens han er i gang med at udtrykke sin bekymring for hende, begynder en telefon at ringe. Manden tager sin telefon og svarer, men telefonens ringen fortsætter. Han er forvirret og bliver ved med at kigge på telefonen i sin hånd, da døren i soveværelsets tøjskab pludselig går op, og en anden mand træder ud kun iført sokker. Han undskylder for ulejligheden og skynder sig søgende over mod en tøjbunke i hjørnet af værelset, alt imens telefonen bliver ved med at ringe. Han finder den, svarer, og bliver straks opslugt i intens samtale. Imens gestikulerer han til det stirrende ægtepar for at udtrykke sin beklagelse over at have forstyrret dem med sit telefonopkald. Som for at minimere denne uhøflige forstyrrelse bevæger han sig tilbage mod skabet, kravler ind, lukker døren efter sig og fortsætter roligt sin samtale indenfor... (Zupančič 2008: 56f.)

Som Zupančič pointerer, er der præcist tale om et konfliktforhold, der opretholdes, i stedet for at eksplodere i vrede og skænderi (eller slagsmål). Komikken begynder naturligvis allerede i det øjeblik, da elskeren i skabet afsløres, men på dette punkt har vi stadig kun at gøre med den samme momentane komiske effekt, som også findes i vitser og gags. Der hvor komikken ifølge Zupančič bliver til komedie er, når konflikten opretholdes og udvikles (når elskeren rent faktisk tager telefonen og begynder at tale, når elskeren efterfølgende ligefrem undskylder overfor parret, og når han til sidst talende vender tilbage til skabet igen).

Med reference tilbage til Hegel kan vi sige, at det er i kraft af sin evne til at få det almene sat i bevægelse og i konflikt med sig selv, at komedien skaber sin særegne form for effekt på tilskueren. Og med reference til Lacan kan vi sige, at det er med artikulationen af konfliktens inkarnation i et objekt, der enten strider mod det symbolske eller det imaginære, at komediens forskellige virkemidler orkestreres. I det givne eksempel er de almene størrelser, der konfronteres, eksempelvis de sociale normer omkring ægteskab og normerne 
omkring høflighed i forbindelse med telefonsamtaler (at tage telefonen når den ringer, ikke at forstyrre uvedkommende osv.), mens det komiske objekt kunne siges at inkarneres i telefonen og den talende - i det faktum, at han rent faktisk bliver ved med at tale, selvom xgteparret ser måbende på, og at situationen således hele tiden udvikler sig yderligere. Mere præcist kan man sige, at i denne scene mærker vi simpelthen, at det umulige på en eller anden måde udfolder sig, og hvad det udfolder sig omkring, er objekt $a$.

Herfra kan man muligvis vove at opsummere Zupančič tilgang til nogle af de forskellige komiske genrer, hendes bog behandler. Karakterkomedien baserer sig for eksempel især på en iscenesættelse og udvikling af inkongruensen mellem jeg'et og det'et, dvs. en inkongruens indlejret i subjektet selv og med objekt a som det umulige objekt for begæret og driften. ${ }^{10}$ Forvekslingskomedien baserer sig på inkongruensen mellem identitet og lighed og kredser således om det reelle objekt $a$ som et konfliktpunkt i det imaginære, som en manifestation af det problem, at enhver identitet, fordi den er dannet gennem spejlinger $\mathrm{i}$ andre, kan fremmedgøre individet, forvirre ham, trække ham med sig ud i alverdens misforståelser og i sidste ende ligefrem kan berøves ham. Farcen eller satiren, den der gør grin med autoriteter og idealer, baserer sig på de interne konflikter i den symbolske orden, dens indre selvmodsigelser, dens kontingente fundament, og dens ultimative mangelfuldhed repræsenteret ved opkomsten af et pinligt objekt $a$ på de mest besynderlige tidspunkter. I familie med sidstnævnte er vitsernes og replikkernes komik, der baserer sig på det symbolskes indbyggede reelle egenskaber, dvs. på kombinationen af sprogets symbolik og dets materialitet.

Set i forlængelse af den tidligere Hegel-diskussion er det også værd at nævne, hvordan begrebet om objekt $a$ passer sammen med teorien om komedie som mediering mellem det almene og det individuelle. Objekt $a$ optræder i spændingsfeltet mellem subjektet og den Anden, som en individuel, eller mere præcist: partikulær inkarnation af det almene-i-arbejde, dvs. som stedet for det almenes konflikt og konfrontation med sig selv.

\section{Komediens etik?}

Imidlertid kan vi nu også vende tilbage til spørgsmålet om det politiske eller etiske aspekt af komedien. Som allerede nævnt kan komedien bruges til at understøtte en given ideologi, når den fungerer som en ventil heri, der tillader subjektet oplevelsen af et slags 'ideologisk frikvarter'. Som eksempel herpå kunne man nævne det årlige karneval, som for et par dage giver arbej- 
derne fri til at drikke, danse, hore, klæde sig ud og lave alskens spas med såvel hinanden som samfundets autoriteter (hvem kender ikke de typiske klip, hvor en politibetjent pludselig har fået en fjerprydelse på hovedet af en glad festivaldeltager?). Men som Zupančič påpeger, er det netop i samme moment, at komedien også kan have en mere progressiv indstilling:

Den zone af subjektivitet, som komedien kan hjælpe os med at bevare og opretholde, er naturligvis grundlæggende ambivalent. Den kan fungere som den distance, der ultimativt hjælper med at opretholde selve undertrykkelsen i en given situation, fordi den gør den udholdelig og fremmer illusionen om en sand indre frihed. På den anden side er det lige præcis et slags overskud, en tom plads for subjektivitet, der danner baggrunden for enhver mulig forandring, og som mobiliseres, når denne forandring finder sted. Det er produktionen af denne form for subjektiveret tom plads, som komediens bevægelse er særligt god til (Zupančič 2008: 216f.).

Komedien danner et frirum for subjektets forhold til den større sociale og symbolske orden, men det afgørende er, hvad der sker med dette frirum. Når det mobiliseres, dvs. når det angribes og fastholdes, i stedet for blot at få karakter af en kortvarig, eksotisk størrelse, kan det have en frigørende effekt.

På dette sidstnævnte punkt er komedien således på linje med den etiske indstilling, der gør sig gældende indenfor den lacanianske psykoanalyse. Som Lacan formulerer det i sit syvende seminar, prædiker psykoanalysen som sit eneste imperativ "ikke at vige tilbage for sit begær" (Lacan 1986: 368). Det betyder netop, at psykoanalysen ikke tillader, at subjektet konstant holder sit begærede objekt $a$ på afstand, som en Ting hinsides al forståelse eller opnåelighed. Et sådant afkald på objektet svarer til at sublimere det, hvilket svarer til at ophøje objektet, så man stadig begærer det, men nøjes med at gøre det fra en vis afstand. Lacan nævner i Seminar 11, at der i mennesket lader til at være en grundlæggende tendens til på denne måde at "ofre" objektet ved at sublimere det: Mennesket nyder at give afkald på mangt og meget, typisk til fordel for en højere sag, en ideologi, en leder eller en guddom (Lacan 1973: 306). Det er den samme effekt, der gør sig gældende, når subjektet i en psykoanalyse "forelsker sig" i sin analytiker og gør vedkommende til et jeg-ideal, det kan måle sig selv i forhold til (idet det dermed så at sige slipper for at vurdere sig selv med egne øjne). Hvad det i stedet handler om er at turde dvæle ved objektet, se det i øjnene så at sige, og derved gang på gang bevidne dets changerende status, først som strålende og fascinerende idealobjekt for begæret, i næste øjeblik som det mest fremmede eller mest simple og materielle, mest reelle objekt. Mens sublimeringens afkald på objektet består i at opret- 
holde en opdeling af objektets konkrete væren og dets glødende hinsidesliggende Tings-hed, består komediens manøvre i konstant at insistere på - og undersøge - deres sammenfald.

\section{Noter}

1 Alle citater fra Zupančič’ bog vil i det følgende være på dansk og oversat af undertegnede. Citaterne stammer fra den danske oversættelse af The Odd One In, som dog endnu ikke er publiceret (udkommer 2011-12 på Forlaget Philosophia), hvorfor de anførte sidetal refererer til den engelske version.

2 Det bør naturligvis nævnes, at der er forskel på latter og komedie, og at Zupančič bog primært beskæftiger sig med det sidste. For et specifikt studie af latteren, hvis tilgang har et vist slægtskab med Zupančič, kan man nævne Anca Parvulescus Laughter: Notes on a Passion (Parvulescu 2010).

3 For en oversigt over Hobbes' beskrivelser af latteren, se Ewin (2001).

4 "Komedien er ikke en slags undergravning af det almene, men dettes (egen) omvending til det konkrete. Den er ikke en protest mod det almene, men det almenes eget konkrete arbejde eller anstrengelse. Eller, for at udtrykke det i en simpel parole: komedien er det almene $i$ arbejde. Det er det almene, der ikke længere (re)præsenteres som handlende, men som er handlende." (Zupančič 2008: 27).

5 Fra filmen af samme navn. Filmen Borat er også et genkommende eksempel i Odd One In.

6 En pointe, der i øvrigt også indeholder sit eget specifikke komiske potentiale: musen har en hund.

7 Lacans omgang med begrebet 'væren' udgør imidlertid ikke en sikkert udviklet teori, hvorfor den ontologiske ambition i Lacans begreber må tages med et vist forbehold. For mere herom, se Balmès (1999) og Dolar (1998).

8 Signifiant og signifié.

9 Ægteskabsinstitutionen er i øvrigt et af de helt store temaer indenfor komedien, og Zupančič behandler det flere gange i sin bog.

10 Denne inkongruens som tager form af et ekstra, faktisk umenneskeligt træk ved den komiske karakter. Det er i lyset af denne pointe, at Zupančič knytter an til Walter Benjamins teori om karakterkomedien: Komiske karakterer er ikke komiske, fordi de indeholder en psykologisk dybde, der gør dem genkendelige for os andre. Tværtimod er de netop komiske, fordi det der kunne være genkendeligt hos dem pludselig overhovedet ikke er det mere (Benjamin 1977; Zupančič 2008: 66). 


\section{Litteratur}

Aristoteles (2009): Poetik, København: Hans Reitzels Forlag.

Balmès, François (1999): Ce que Lacan dit de l'être (1953-1960), Paris: Presses Universitaires de France.

Benjamin, Walter. (1977): "Schicksal und Charakter" i Gesammelte Schriften (Vol. 2.1), Frankfurt am Main: Suhrkamp Verlag.

Bergson, Henri (1993) [1900]: Latteren - et essay om komikkens vasen, København: Politisk Revy.

Dolar, Mladen (1998): "Cogito as the Subject of the Unconscious" i Slavoj Žižek (red.), Cogito and the Unconscious, Durham: Duke University Press, s. 11-40.

Ewin, R. E. (2001): “Hobbes on Laughter", The Philosophical Quarterly, vol. 51, nr. 202, s. $29-40$.

Freud, Sigmund (1994) [1905]: Vitsen og dens forhold til det ubevidste, Frederiksberg: Det lille Forlag.

Hegel, G. W. F. (2005) [1807]: Åndens fænomenologi (overs. af C. B. Østergaard), København: Gyldendal.

Hobbes, Thomas (1996) [1651]: Leviathan. London: W. W. Norton \& Co.

Lacan, Jacques (1986): L'éthique de la psychanalyse (1959-1960) (Le séminaire, livre VII), Paris: Éditions du Seuil.

Lacan, Jacques (1973): Les quatre concepts fondamentaux de la psychanalyse (1964) (Le séminaire, livre XI), Paris: Éditions du Seuil, edition "Points".

Parvulescu, Anca (2010): Laughter: Notes on a Passion, London: The MIT Press.

Zupančič, Alenka (2008): The Odd One In: On Comedy, Cambridge, Massachusetts: MIT Press. 
